\title{
Drivers of corporate social responsibility within construction organization in Nigeria
}

\author{
Samuel Ekung ${ }^{1}$, Anthony Ujene ${ }^{2}$, Ubong Ebong ${ }^{3}$ \\ ${ }^{1}$ School of Built Environment, University of Salford, Greater Manchester M5 4WT, United Kingdom \\ 2Department of Building, Faculty of Environmental Studies, University of Uyo, Uyo, Nigeria \\ ${ }^{3}$ Department of Building, School of Environmental Studies, Akwapolya, Ikot Ekpene, Nigreria
}

\begin{abstract}
This paper examined the drivers of corporate social responsibility within construction organisations in Nigeria. The objectives were to determine the critical factors driving corporate social responsibility implementation in Nigeria and to examine the level of its uptake. It involved a semistructured interview conducted on 36 respondents. The sample include 4 key accountable persons in four constructions firms in Akwa Ibom State Nigeria; 16 employees comprising four from each firm and 16 community stakeholders in which these firms had executed projects in the past six years. Qualitative data collected were sorted and interpreted. The need to mitigate community stakeholder's risk; government push, competitive advantage and diverting attention of key stakeholders are the key drivers of corporate social responsibility among construction organisations in Nigeria. There is also a wide uptake of corporate social responsibility although with limited implementation in key areas in the social and environmental agendas. Constructions organisations need be innovative in their implementation policy while exploring ways to improve on the agendas where there are lapses in order to be social responsible organisations. The study provides an understanding of the most critical barrier to creating a safe commercial environment devoid of stakeholders' opposition.
\end{abstract}

Keywords: corporate social responsibility; construction organisations; drivers; Nigeria and uptake

\section{INTRODUCTION}

Research into corporate social responsibility began in 1950s and the fundamentals were established in the 70s. These earlier studies provide the foundation upon which subsequent studies mainly in the business sector utilized to establish ethical and moral justification for CSR in the 90s. Such justifications is anchored on the indispensability of the business stakeholders particularly the community and the customers (Carroll, 1990); competitive advantages (Martinuzzi et al., 2011), the need to curb pressure from external stakeholders (Rowley, 1997), and reputable image building (Doane, 2005). Among construction organisations, impetus for CSR uptake is hinged on the extensive impact of construction on the environment (Glass \& Simmonds, 2007).

Cartlidge (2011) reports that, construction works account for over $30 \%$ waste generated in the UK and his responsible for over $40 \%$ carbon related problems around the globe. Boudet et al. (2006) also identified infrastructure as a source of conflict in many communities. 
Loosemore (2000) asserts infrastructure contracts embed a plethora of conflict triggers that often develop into crisis if not well managed. As a result of the relationship between the environment and construction, construct such as community protest is engaging academic research interest (Teo, 2009) and most project environments are now christened controversial (Teo \& Loosemore, 2012).

Several studies have considered construction industry's Corporate Social Responsibility (CSR) (Martinuzzi et al., 2011; Barthope, 2010; Arslan \& Kivrak, 2008; Sonja, 2008; Glass \& Simmonds, 2007; O'Connor \& Spangenberg, 2007; Kolk \& Pinkse, 2006; and Jones et al.; 2006) across Europe and the UK. Jones et al.; (2006) examined CSR issues and agenda undertaken by the UK leading construction firms; Sonja examined CSR practices among leading Australian construction firms, Kolk \& Pinkse (2010) analyses the extent in which CSR are integrated into corporate governance structure of firms in Netherlands and found that many multi-nationals maintain a separate corporate governance section in their CSR. O'Connor \& Spangenberg (2007) develop CSR "Deliberation Matrix" for structuring CSR issues identification. The overriding findings in these studies centres on the use of CSR for improve image building; focusing on environmental, health and safety issues and local community integration into the corporate management structure of the companies.

CSR interest in construction gained prominence in late 2000. Successive researchers have acknowledged wide spread adoption of CSR in the construction across Europe and the UK and other developing countries but none has been conducted in Nigeria's construction sector. Previous research theme focused on the impact of construction activities on the environment and practices across sectors. Studies on the critical drivers of CSR among construction organisations are few and the level of CSR uptake in Nigeria is not apparent.

The present study therefore seeks to the answer the following research questions:

i. What are the critical drivers of CSR among construction organisations in Nigeria?

ii. To what extent is CSR adopted by leading construction organisations in Nigeria?

\section{NIGERIA'S CONSTRUCTION INDUSTRY}

The Nigerian construction industry has witnessed significant growth since 2011. The contribution to GDP is $1.4 \%$ (Oluwakiyesi, 2011). Despite this growth index, the sector is yet to realise its full potential given the huge deficits in infrastructure development Nigeria is faced with. The Nigerian government at the moment invest about $7.5 \%$ of its GDP in the construction sector with a goal to double the digit in the near future (Sanusi, 2012). This portrays a haven of opportunity for key players and investors.

With significant improvement in budgetary implementation, emphasis on accountability and transparency, the industry is set to overcome its major growth inhibitors in a number of years to come. Efforts are also in top gear to improve local content in the production of construction inputs mainly cement and the revitalisation of various steel mills to improve production. Indicators in strong growth and economic diversification; rapid urbanisation, demographic housing demand, strong commodity prices in the long term and increasing private sector participation, hints the industry is catalysed for efficiency (Oluwakiyesi, 2011).

The Nigeria construction industry is dominated by international firms' although a number of small indigenous firms also exist.

But their growth is not rapid due to the lack of effective government legislation to support their emergence. The market leader is Julius Berger -German firm although the entrance of Chinese giant CCECC is set to reduce their dominance based on their incentives packages. 
There are also a score of medium sized firms championed by nationals from Italy (Gitto), Lebanon (Setraco), and numerous indigenous participants in this category (Dantata \& Sawoe). They are productively engaged by government at all levels and private sectors in different parts of the country. Sustainable organisations are rooted in ethical social responsibility practice according to the stakeholder theory.

\section{CORPORATE SOCIAL RESPONSIBILITY IN CONSTRUCTION}

In Nigeria, corporate social responsibility is part of the larger obligation of the firm to it community under extant law notably where natural resources is explored. The moral obligation of firms on CSR is a well debated issue among academics and industry experts. Barney (2007) argued for its usefulness as a mechanism for improving financial status and the overall property of the stakeholders.

Andayani \& Atmini (2012) found a correlation between CSR and improved firm's performance in Indonesia. This is based on the threesome of the firms' CSR effort to promote economic prosperity, promote health \& safety and preserve the environment. The economic prosperity is based on theory which view's the firm as a "money making machine" for the stakeholders; training of personnel and development of local supply chain (Bouma, 2002). In the construction industry, CSR activities focus on occupational health \& safety, security, and sustainable construction (Martinuzzi et al., 2011 and Glass \& Simmonds, 2007). Imperative is on the need for CSR activities in construction to stand out as an example in public procurement, set out standards, enforce the implementation of existing culture of regulations and fight endemic corruption.

Barney (2007) views CSR as an action of the company to improve the situation of the society and its environment. While this view provides the basis for moral justification for the wide uptake of CSR across many sectors; some school of thought argues the firm is only accountable to its shareholders (Carroll and Sundgren, 1996 in Andayani \& Atmini (2012). The implication therefore is that, research on the subject had been inconsistent until late 2000s. Based on the view which associates CSR with responsibilities to the society and stakeholders, Andayani \& Atmini (2012) therefore opined it is a "voluntary action" of the company to enhance the situation of the society and the environment.

The World Bank maintains CSR is the duty of the company to give responsibly to the society (Doane, 2005). Earlier studies by Friedman (1984) did not support CSR to the society but however associates the obligation of the company to wealth maximization for the shareholders.

The Friedman position originates from stakeholders theory which defines stakeholders as a group of people or individuals who can influenced or be influenced by the motives of the company. Given the wider view held about environmental and economic prosperity ambient of the CSR cores, the view held by Friedman cannot discredit the established relationship. Firms with CSR commitment are therefore seen to have public interest in competition with their corporate goals. How is the success of CSR in construction measured?

\section{CSR SUCCESS FACTORS IN CONSTRUCTION}

The emphasis on sustainable construction and sustainability issues has really exposed the reprehensible treatment meted on the environment in the past. If construction impacts the 
environment (Glass \& Simmonds, 2007), the motivation to address the needs of the stakeholders is only instrumental otherwise the firm cannot function effectively (Kolk \& Pinkse, 2006). The determinant of success in the construction industry has been project based where cost, time and quality underscore the parameters. Very few studies have examined performance of the construction firms as correlate of project's performance (Andayani \& Atmini (2012). Toor \& Ogunlana (2008) and Arslan et al., (2008) are among the very few who have studied project performance in this regard. Arslan et al. (2008) examine the performance of projects using parameter such as the ability to plan and execute project successfully. If the work environment and the activities of the external stakeholders are determinants of project success; CSR should have impact on the outcome of projects. Toor \& Ogunlana, (2008) on the other hand, established stakeholder's relationship as key to project success in context with construction firms. Arslan et al., (2008) undertook an extensive empirical review and identified critical success factors to include business management, financial conditions, and owner/manager's attributes (Martinuzzi et al., 2011).

Aspect of the environmental friendliness has been extensively studied in the UK by Griffiths \& Bhutto (2008). They conclude with an emphasis on the need for contracting firms to treat seriously, the environmental concern in order to remain competitive. The external environment is one of the critical ambient of Chan's (2004) critical success factors in construction. Chan had identified industrial relations, economic, social, and physical environment. The lack of industrial harmony due to external stakeholder's pressures has been on the forefront of delay in highway construction in Nigeria (Awotunde, 2010). Zhao et al. (2012) attempted a more comprehensive and broad base study on CSR critical success factors in construction. They developed 30 performance indicators based on the need of 11 stakeholders groups relating to both internal and external stakeholder groups anchored mainly on economic, environment and health and safety issues.

Nevertheless, the competitive nature of the construction industry strongly impedes effective uptake of CSR by construction firms thereby disposing the firm to the debate between the need for CSR and their firm's commercial objectives. The melting point as seen from the foregoing argument is that, CSR does not really involve additional responsibility and cost but strictly entails ethical implementation of good practice. Training in this case is essential while a concerted effort must be made to understand which is more important to external stakeholders in every project situation. The cooperation of relevant stakeholders is equally important: property developers, contractors, investors, the larger user group and owner (Zhao et al. 2012).

These groups do not only decide the cost structure but are relevant in shaping the adequacy of environmental and societal impacts (Mattinuzzi et al., 2011). In the opinion of these authors, if any of the parties desire CSR, CSR measure can be implemented. They established a link between non-implementation of CSR measures as a critical societal obligation and intense pressure on the work site. Crespin-Mazet \& Flipo (2009) analysed practices created by competitive bidding and found that public procurement does represent a realistic framework to favourable ethical CSR in the construction industry. They emphatically pinpointed lowest price bid as a correlate of unethical practices in the construction industry. CSR is an ethical parameter since it concerns firms' moral obligation to the society. CSR is a "distributive justice" (Crespin-Mazet \& Flipo, 2009) instrument which evaluates the inputs made to satisfy the community and what commensurate profit is obtained by the firm. Given these impediments and success factors, what then drives firms' uptake of CSR. 


\section{DRIVERS OF CSR AMONG CONSTRUCTION SUPPLY CHAIN}

The motivations that steers businesses implementation of CSR have been widely debated in the 80s and 90s. However, current thinking in the business sector tends to favour the justification which views CSR as an ethical obligation of the firm to the stakeholders. Different organisations implement CSR for various reasons. While many are entirely economical to corporate survival of the business, other motives are deeply rooted in image making and others in environmental concerns. Human resources, risk management, brand differentiation, licence to operate; diverting attention (Bromhill, 2007) are relevant drivers of global leading enterprises. CSR help to build 'feel good' sensation among staff stock. Effective CSR can facilitate the mitigation of policy risk and community protest that earmarks most projects in construction industry. In the competitive market place, differentiation of brand is a selling point that distinguishes businesses. In the construction industry, it might take the form of job type, client, method of execution, diversification into other fields and enlisting in the stock exchange.

A business which embeds CSR in their corporate governance culture is at liberty to operate in environment where their impact is felt and are confident of patronage from clients. Sometimes, businesses use CSR to divert the attention of regulatory bodies, civil liberty organisations and even downstream stakeholders in the project community. The nature of the industry itself is also a major driver. Attracting clients and investors to engage the firm's services is enough to mandate CSR. Competitive advantage is also a key driver of CSR (Andayani \& Atmini, 2012); it open up space for enterprises that can differentiate themselves. Mistrust in the legal system has been identified as an obstacle as well market place decisionmaking framework (Williamson et al., 2006). Nguyen (2013) identified internal and external drivers of CSR in developing countries. External drivers are international standardization; investment incentives and stakeholders activism and supply chain. Internal drivers include: cultural tradition; political reform; socio-economic priorities; governance gaps; crisis response and market access. He argued that the internal drivers impact more on the local communities. Government also steers significant implementation of CSR agenda in UK (Moon, 2004). The need to secure increased consumer and customer based and demand also engender uptake among firms. These conceptual frameworks are used in the evaluation of the potential drivers for CSR uptake in the case studies.

\section{RESEARCH METHODOLOGY}

This study is a case study of four multinational construction enterprises operating in Akwa Ibom State. A convenient sample of 36 respondent selected using purposive sampling from three stakeholders group were interviewed in three layers. The use of non-probabilistic sampling technique is prompted by the lack of accurate number of required characteristics in the sample studied. This method is also widely used in construction research. Akwa Ibom state was selected for the study based on the volume of on-going infrastructure development in the state. These firms have been steadily engaged in the past six years in this region. A semistructured interview was adopted in generating relevant qualitative data.

Projects studied were mainly road contracts. The method was selected based on its flexibility that allows the researcher to probe the interviewee to reflect his thought and feelings (Farrell, 2011). A three tier interview using definitive questions was carried out. First, key accountable person in each organisation was interviewed. This was to determine the critical drivers for CSR uptake and the CSR agenda their organisation implement. Second, four 
representatives each from communities in which these organisations have executed projects were interviewed to confirm data from the first phase of the interview. Thirdly, key employees at the line management level in each firm were interviewed. This group was considered suitable among the employees because they possess substantial knowledge about the firms' practices affecting them and other employees under them. Identified respondents in each firm were notified of the intentions of the study to enable them carry-out their individual research within their organisations. The interview questions were theme on the two main objectives and featured 12 questions in all categories. Interviews were sorted along the major theme gathered collectively and individually from the literature to enhance analogy.

\section{FINDINGS AND DISCUSSION}

In Table 1, specific CSR agendas were examined to determine the extent in which firms implement and the beneficiaries' level of satisfaction. The economic agenda are generally satisfactory as the firm's delivery is maximally satisfactory in terms of timely delivery and quality. Community suppliers are equally engaged and paid regularly while the compliant handling system is considered efficient. Significant compliance is recorded with social factors but there is immense room to improve in some areas. So much can be done; the firms need to be innovative in their implementation.

Work life balance associated factors must be improved while the working time need be adjusted to standard 8 hours. Most workers worked between $8 \mathrm{am}$ to $5 \mathrm{pm}$ and have to depart for work as early as $6 \mathrm{am}$ and return home at $7 \mathrm{pm}$. There is slight variance in the opinion of firms' responsible persons interviewed with communities' stakeholder in factors relating to environmental protection issues.

The communities complained flood cases and the impact of on-going construction work on the socio-economic wellbeing. Some of the respondents reports thus "sometimes the roads are not 'motorable' and even our house and business premises cannot be accessed by our customers for a long time"'. This reflects a serious environmental concern lapses. The need for improvement on the global implementation of corporate social responsibility is universal. Studies in Australia (Sonja, 2008) and in the UK (Glass \& Simmonds, 2007) conclude by acknowledging total implementation in all spheres of corporate social responsibility agenda to be ethically responsible.

Knowledge about CSR seems to be wide spread and its implications within the construction organisation studied. As seen in Table 2, the total population interviewed indicates significant level of awareness. Does the awareness translate into implementation? The study sought to determine the effectiveness of individual firms' policy based on six criteria.

The co-option of corporate social responsibility as a corporate business concern and not being seen as a mere moral objective. Every firm agrees to this notion. CSR is intrinsic with their businesses and are separated from the corporate business objectives of the firms. 
Table 1. Compliance with Specific CSR Agendas.

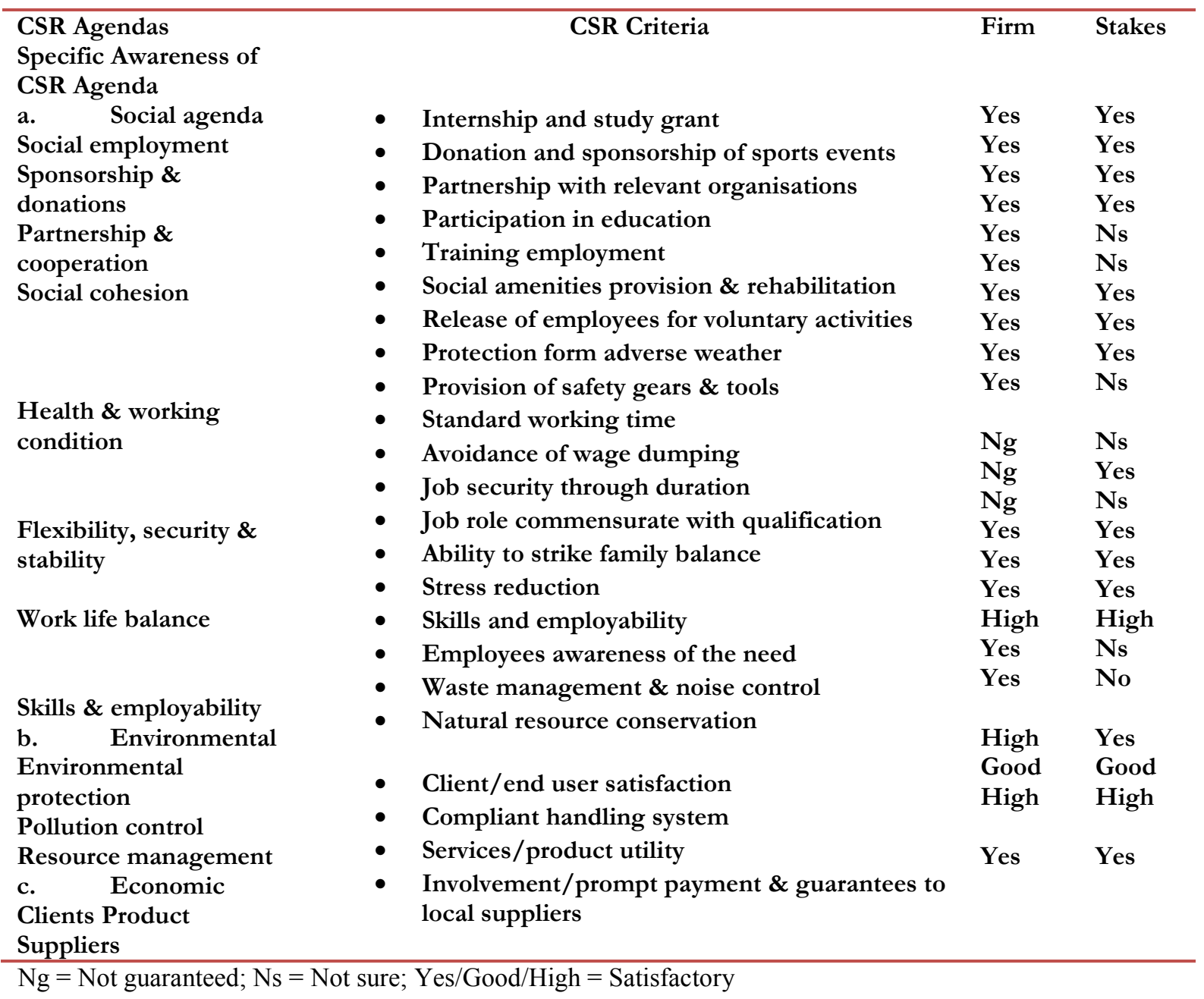

Table 2. CSR Policy Design and Critical Drivers.

\begin{tabular}{|c|c|c|}
\hline Assessment Criteria & Parameters Descriptors & $\begin{array}{c}\text { Level of } \\
\text { Application }\end{array}$ \\
\hline \multicolumn{3}{|l|}{ CSR Policy } \\
\hline CSR Awareness & $\begin{array}{l}\text { General awareness based on established conviction on the } \\
\text { need to partner external communities }\end{array}$ & $100 \%$ \\
\hline Objectivity of CSR Aim & $\begin{array}{l}\text { Tendency to consider CSR as a business corporate need } \\
\text { rather than mere moral argument }\end{array}$ & $100 \%$ \\
\hline Definition of Objectives & $\begin{array}{l}\text { General clarity about the aims and objectives of CSR and } \\
\text { commitment to achieve long term benefits }\end{array}$ & $75 \%$ \\
\hline CSR Culture & $\begin{array}{l}\text { The rate in which CSR is perceived or considered as an } \\
\text { organisational culture }\end{array}$ & $75 \%$ \\
\hline $\begin{array}{l}\text { Performance Assessment } \\
\text { Innovation }\end{array}$ & $\begin{array}{l}\text { Instituted performance assessment criteria to evaluate result } \\
\text { and measure performance } \\
\text { Innovative implementation to suit needs }\end{array}$ & $25 \%$ \\
\hline \multicolumn{3}{|l|}{ Key Drivers of CSR } \\
\hline $\begin{array}{l}\text { Policy } \\
\text { Government push }\end{array}$ & $\begin{array}{l}\text { Mandated by the public authority through law and } \\
\text { enforcement }\end{array}$ & $70 \%$ \\
\hline Stakeholders demand & Push from relevant stakeholders & \\
\hline Human resource & The needs to attract workforce & $40 \%$ \\
\hline
\end{tabular}




\begin{tabular}{lll}
\hline Project Environment & $\begin{array}{l}\text { Use in mitigating risks associated with the project } \\
\text { environment }\end{array}$ & $85 \%$ \\
Competitive advantage & Creating a niche in the market and brand differentiation & $80 \%$ \\
Strengthened legal & Concerned by costly redress in law as a result of & $56 \%$ \\
systems & strengthened system and due NGO activities & $70 \%$ \\
\hline Diverting to attention & Used as a means of diverting public attention \\
\hline
\end{tabular}

A respondent asserts 'it is one of the pillars in which our company ethics is built'. There is however a slight deviant in respect of each firm possessing clear objective of what their corporate social responsibility entails; in which case only $75 \%$ of the firms tend to have well defined objectives. However, $75 \%$ of the firms do not have established benchmarks for evaluating CSR programs while there seems to be also, an embedded culture of ethical responsibility only in $75 \%$ of the firms. Only $25 \%$ are innovative in the implementation of CSR different from the established guidelines set by the law. This is inconsistent with the findings in Glass \& Simmonds (2007). They found in their study on Considerate Constructor Scheme implementation in the UK, firms questioned the rational in which they were told what to do. According to a respondent in their study, there appears to be more a firm can do economically and socially to improve the work environment and its people. However, these criteria has been adjudged adequate and use for the evaluation of business enterprise's CSR in the business sectors (McKinsey, 2011 and Kakabade \& Kakabade, 2011). Recent study on CSR uptake in the UK (Barthope, 2010) indicates significant embrace of innovative implementation of CSR and gives a comprehensive account of benefit to both local and international communities. Similarly, the finding on the treatment of corporate social responsibility matter as a separate governance issue; corroborates the findings in Kolk and Pinkse (2010). In a study of 250 firms in the Netherlands, Kolk and Pinkse affirmed more than half of the study population maintain a separate section for CSR.

A number of factors drive firm's implementation of CSR in the construction industry in Nigeria. Factors relating to the project environment that is, the need to promote relaxed environment and cooperation of local stakeholders lead other factors on the percentile scale. Business drive for competitive advantage over market competitors is the second most critical driver while government push and CSR widely use in diverting attention are ranked third on the percentage scale.

The push from government subsists in the use of CSR to solve or alleviate socioeconomic problems at the downstream stakeholder's level. Diverting attention driver is associated with the desire to appease public authority. This includes embarking on emergency repairs and rehabilitation of roads outside their contract domain. This factor is widely employed and used. There is also the negative aspect in which if not properly monitored can be used to abate corrupt practices across different sectors. Another factor, the need to attract workforce and avoidance of costly redress where court action is involved was scored below average, and average. The findings with human resource is not surprising, giving the depth of unemployment in the country, workforce concern very minimally about work ethics and conditions; rather emphasis is on the wage. The findings of the study corroborate previous studies findings except human resource driver. Fernando (2007) and Visser (2008) had found this factor relevant in the study of CSR drivers in Vietnamese business sector. Visser (2008) found that CSR is used to explore gaps in socio-economic provision where government resources are inadequate or to enable the government focused on other sectors in need. Fernanado found that CSR was increasingly adopted to ameliorate crisis situations. 
Similarly Moon (2004) identifies government as a factor behind increasing uptake of CSR in developing countries. These conclude the research effort to determine critical drivers and level of CSR uptake in Nigeria.

\section{CONCLUSIONS}

Corporate Social Responsibility is seen to be sine qua non for every responsible business' success globally, and across different industries including construction. While there are many studies in the area in many developed and some developing countries, none has been conducted in the Nigerian construction sector. This study explored the level of CSR uptake by leading construction enterprises in Nigeria and their drivers. A semi-structured interview which is widely used in related studies was adopted to generate qualitative data for the study. The study explored critical drivers for CSR in the construction sector and found that CSR is widely driven by need to mitigate community stakeholders risk at the work site. The need for competitive advantage; the need to divert attention of relevant stakeholders from the firm's activities are other relevant factors identified. Government push to fill the gap in the provision of basic amenities and in solving socio-economic problems was equally significant.

Corporate social responsibility is also widely adopted in the Nigeria construction industry although there is a slight variant in the implementation of certain agendas relating to social and environmental factors. For firms to be a corporate social responsible stakeholder there must be total adherence in the implementation of all aspect of the corporate social responsibility agenda. The existing CSR framework should be seen as a basic requirement in which the firms can always improve on by being innovative. There is a very low level of innovation in the implementation of corporate social responsibility by the construction enterprise in Nigeria. The law only set minimum standard and not the upper limit of what can be done.

This study provides an insightful review of issues in the area of CSR in the Nigerian construction industry. It might interest other researchers to explore the factors constituting implementation problems in the area identified. By providing a generic review of parameters that can be used to evaluate the construction enterprise CSR policy and performance; the construction enterprises in Nigeria have valid benchmark to improve on their performance if they must stay competitive.

\section{References}

[1] Andayani, W. \& Atmini, S. (2012). Corporate Social Responsibility (CSR), Good Corporate Governance (GCG), and Firm Performance, Journal of Modern Accounting and Auditing, (8)10: 1484-1495.

[2] Arjen, A.; Mark, A. J. H.; Lucas, R. (2005). Human Health Damages due to Indoor Sources of Organic Compounds and Radioactivity in life Cycle Impact Assessment of Dwellings, International Journal of Life Cycle Assessment, 10(6): 383-392.

[3] Arslan, G. \& Kivrak, S. (2008) Critical Factors to Company Success in the Construction Industry, World Academy of Science, Engineering and Technology, 45: 404-407. 
[4] Awotunde, G.B. (2010). An Evaluation of Risk Factors Impacting Highway and Road Projects in Nigeria, in Wang et al., Proceedings $8^{\text {th }}$ International Conference on Construction \& Real Estate Management 336-344 available online at: http://arrow.unisa.edu.au:8081/1959.8/119503, accessed 4/4/2013

[5] Barthope, S. (2010). Implementing CSR in the UK Construction Industry, Property Management, 28(1): 4-17.

[6] Barney, J. B.; Mackey, A.; \& Mackey, T. B., (2007). Corporate Social Responsibility and Firm Performance: Investor Preferences and Corporate Strategies, Academy of Management Review, 32(3): 817-835.

[7] Boudet, H.S. Chinthana, J. \& Davis, J. (2011). Drivers of Conflict in Developing Country Infrastructure Project: Experience from the Water and Pipelines Sectors, Journal of Construction Engineering and Management, 137(7): 498-511.

[8] Bouma, E. (2002). Sustainable Development and Corporate Responsibility, FCGI in Indonesia.

[9] Broomhill, R. (2007). Corporate Social Responsibility: Key Issues and Debate, Don Dunstan Foundation for the Duncan Papers Series, available: accessed 3/6/13. http://www.som.cranfield.ac.uk/som/dinamic- content/research/doughty,

[10] Carroll, A. (1999). Corporate Social Responsibility: Evolution of Definitional Contract, Business \& Society, 38(3): 269-295

[11] Cartlidge, D. (2011). New Aspect of Quantity Surveying, Oxford: Butterworth Publishing Ltd.

[12] Chan, A.P.C., Scott, D., Chan, A.P.L. (2004) Factors Affecting the Success of a Construction Project. Journal of Construction Engineering and Management, 130(1): 153-155.

[13] Crespin-Mazet, F. \& Flipo, J. (2009). Marketing and Ethics in Competitive Tendering Procedures, $25^{\text {th }}$ IMP Conference in Marseilles, September, available: http://www.impgroup.org/paper_view.php?viewPaper=7328, accessed 2/6/13

[14] Doane, D. (2005). Beyond Corporation Social Responsibility: Minnows, Mammoths, and Markets. Futures, 37: 215-229

[15] Fernando, M. 2007. Corporate Social Responsibility in the Wake of the Asian Tsunami: A Comparative Case Study of Two Sri Lankan Companies, European Management Journal, 25(1): 1-10.

[16] Glass, J. \& Simmonds, M. (2007). Considerate Construction": Case Studies of Current Practice, Engineering, Construction and Architectural Management, (14) 2: 131-149.

[17] Griffith, A., Bhutto, K. (2008) Improving Environmental Performance through Integrated International Journal, (19)5: 565-578.

[18] Jones, S. \& Howarth, S. (2012). Supporting Infrastructure Development in Fragile and Conflict-Affected States: Learning from Experience, Oxford Policy Management, Matt MacDonald, available http://www.opml.co.uk/sites/opml/files, accessed 3/6/13.

[19] Jones, P.; Comfort, D.; \& Hillier, D. (2006). Corporate Social Responsibility and the UK Construction Industry, Journal of Corporate Real Estate, 8(3): 134-150. 
[20] Kakabadse, N.; Kakabadse, A.; Lee-Davies, L. (2009).CSR Leaders’ Road- Map, Corporate Governance, 9(1): 50-57.

[21] Kolk, A. \& Pinkse, J. (2006). Stakeholder Mismanagement and Corporate Social Responsibility Crises, European Management Journal, 24(1): 59 -72.

[22] Kolk, A. \& Pinkse, J. (2010). The Integration of Corporate Governance in Corporate Social Responsibility Disclosures, Corporate Social Responsibility and Environmental Management, 17: 15-26.

[23] Loosemore, M. (2000). Crisis Management in Construction Projects, Virginia: ASCE Press.

[24] Mackey, A.; Mackey, T. B.; \& Barney, J. B. (2007). Corporate Social Responsibility and Firm Performance: Investor Preferences and Corporate Strategies. Academy of Management Review, 32(3): 817-835.

[25] Martinuzzi, A.; Kudlax, A.; Faber, C.; \& Wiman, A. (2011). CSR Activities and Impacts of the Construction Sector, Sector Profile Based on a Literature Review Developed in the Course of the FP7 Project IMPACT- Impact Measurement and Performance Analysis of CSR, Wien Vienna University of Economics and Business, Austria.

[26] McKinsey Quarterly. (2011). The Business of Sustainability: McKinsey Global Survey Results Available at: https://www.mckinseyquarterly.com, accessed 4/5/2013.

[27] Moon, J. (2004). Government as a Driver of Corporate Social Responsibility, Research Paper Series, International Centre for Corporate Social Responsibility, Nottingham University.

[28] Nguyen, V. (2013). Corporate Social Responsibility Implementation by Vietnamese Enterprises, Thesis submitted to the Department of International Business, University of Lahti University of Applied Science, available:

http://publications.theseus.fi/bitstream, accessed on 23/4/13.

[29] O’Connor, M. \& Spangenberg, J. (2007). A Methodology for CSR Reporting: Assuring a Representative Diversity of Indicator across Stakeholders, Scales, Sites and Performance Issues, Journal of Cleaner Production, 16: 1399-1415.

[30] Oluwakiyesi, T. (2011). Construction Industry Report, A Haven of Opportunities, Abuja: VETIVA Capital Management Limited, available: http://www.proshareng.com/admin/upload/reports/ accessed 4/3/13.

[31] Rowley, T.J. (1997). Moving Beyond Dyadic Ties: a Network Theory of Stakeholder Influences, The Academy of Management Review, 22(4): 887-910.

[32] Sonja, P. (2008). The Development of Corporate Social Responsibility in the Australian Construction Industry, Construction Management and Economics, 26(2): 93-101.

[33] Sanusi, L.S. (2012). The role of Development Finance Institutions in Infrastructure Development: what Nigeria can learn from BNDES \& the Indian Infrastructure Finance Company, Key Note Address at $3^{\text {rd }}$ ICRC PPP Stakeholder Forum, July 18th? 
[34] Teo M.M.M and Loosemore M (2012) A New Research Agenda into CommunityBased Protest in Construction In: Smith, S.D (Ed) Procs 28th Annual ARCOM Conference, 3-5 September, Edinburgh, UK, Association of Researchers in Construction Management, 1135-1143.

[35] Teo, M. (2009). An investigation of Community-based Protest Movement Continuity against Performance. Academy of Management Journal 42(5), 488-506.

[36] Toor, S. R., Ogunlana, S. O. (2008). Critical COMs of Success in Large-Scale Construction Projects - Evidence from Thailand Construction Industry, International Journal of Project Management, 26(4): 420-430.

[37] Visser, W. (2008). Business Frontiers, ICFAI University Press. Hyderabad

[38] Williamson, D.; Lynch-Wood, G. \& Ramsay, J. (2006). Drivers of Environmental Behaviour in Manufacturing SMEs and the Implications for CSR, Journal of Business Ethics, 67: 317-330.

[39] Zhao, Z.; Zhao, X.; Davidson, K.; \& Zuo, J. (2012). A Corporate Social Responsibility Indicator System for Construction Enterprises, Journal of Cleaner Production 29(30): 277-289. 